\title{
Immune intervention yes, but for what reason, for whom, when and how?
}

\author{
A. Lernmark \\ Department of Medicine, University of Washington, Seattle, Washington, USA
}

The hypothesis that Type 1 (insulin-dependent) diabetes mellitus is an autoimmune disease has yet to be proven. The many phenomena of immune character associated with the clinical onset of Type 1 diabetes are used to support this hypothesis. However, too many questions remain unanswered. We would probably make tremendous progress if the hypothesis were to be disproved, since it would force us to formulate new hypotheses. Taking the immunological perspective for now, when does the initial antigen presentation take place, what are the antigen(s), and are they the same in every pre-diabetic subject? Specific T-cell participation is taken for granted, but to my knowledge, human T cells, be they CD4 + cells that proliferate in response to a specific Beta-cell antigen, or CD8 + cells that kill Beta cells, have yet to be demonstrated convincingly. The assays for islet cell autoantibodies are becoming more reproducible and progress is being made by joint international efforts to develop standardized assays $[1,2]$. The availability of defined antigens, first insulin [3] and now also recombinant glutamic acid decarboxylase(s) (GAD) [4-8] makes it possible to study these antibodies using quantitative, validated assays. More antigens are apparently also waiting to enter the stage. In this brief commentary, I would therefore like to put the problem of intervention therapy into perspective by asking: for what reason should it be used, who should be treated, and when, and how to treat?

\section{Intervention - for what reason?}

Although more studies are needed, it seems reasonable to assume that the presence of islet-specific antibodies act as a marker for something abnormal since they are rare in healthy people. Since at the time of clinical onset diabetic patients tend to have several of these antibodies, does this not mean that we are looking at an immune reaction that is secondary to Beta-cell destruction? What is the primary event that triggers Beta-cell destruction? In this respect, the same question about
Beta-cell specific $T$ cells cannot be asked since in man they remain to be demonstrated. Recent observations in the BB rat [9], the NOD mouse [10], in transgenic mice expressing the haemagglutinin antigen [11] and also in man (A. Lernmark, unpublished data), all suggest that macrophages infiltrate islets before lymphocytes. What are the events which recruit these inherent antigenpresenting cells? The insulin granules in islet macrophages $[12,13]$ may be a memento of Beta-cell death of uncertain origin. The presence of insulin-positive MHC class II antigen-expressing macrophages refute the hypothesis that aberrant expression of class II molecules initiates Beta-cell autoimmunity. When patients with recent-onset Type 1 diabetes are subjected to immunotherapy, we have to make it clear to ourselves and the patients whether it is a primary or secondary disease that is being treated.

The exquisite specificity of the immune system response to foreign antigens is truly amazing. The memory of the immune system is equally remarkable. In diabetes research, rapid rejection after pancreas transplantation between monozygotic twins was an ample alert [14]. We therefore face a formidable task: to halt or reverse an established immune reaction. In other words, how would one go about erasing an immune response, established by auto-vaccination, which remains with the individual from birth to grave? However, there is hope, since the many observations of immune abnormalities prior to and at the clinical onset of the disease have unveiled a multitude of possible approaches to immunotherapy both at the time of clinical diagnosis. The and before numerous molecular interactions forming an immune response offer as many if not more possibilities for intervention as there are investigators in the field. This is reflected in the article by Pozzilli and colleagues, who suggest a number of therapies that are all rational. In fact, they only scratched the surface of possible immune intervention strategies. We need to make clear for what reason intervention is to be attempted: to prevent a primary process or to interrupt a secondary one? 


\section{Who should be treated}

Observations of islet cell antibodies (ICA) in families with Type 1 diabetes have resulted in the conclusion that there is an islet autoimmune prodrome of varying length. Several prospective family studies were initiated worldwide, yet the numbers of converters (i.e. marker-positive individuals who developed Type 1 diabetes) have been disappointingly few. At the same time, the lesson to be learned from the epidemiology of Type 1 diabetes is that only about $10 \%$ of children and young adults with recent-onset Type 1 diabetes have a first degree relative with the disease [15]. A telling example can be taken from Sweden and Finland, the two countries with the highest known cumulative incidence rate at ages under 15 years (about $0.4 \%$ ). This translates into 400 children who will develop the disease in Sweden out of roughly 100,000 children born each year. Intervention in families with Type 1 diabetes would treat 40 pre-diabetic individuals, however 360 children would still develop the disease, unreachable by a trial among first degree relatives. Since some older patients presenting with Type 2 (non-insulin-dependent) diabetes, might progress to Type 1 diabetes, this is one group to consider treating. But it is clear that most new cases of Type 1 diabetes occur in the general population.

\section{When to treat}

What would be the result of screening the population for diabetes gene and ICA markers? First, screening for the presence or absence of aspartic acid (asp) at position 57 of the DQ $\beta$ chain gene is out of the question since $2 \%$ of Swedish Type 1 diabetic children are asp/asp homozygous and some $20 \%$ asp heterozygous. Second, disregarding unknown factors such as the length of the prodrome and with no knowledge of susceptibility genes other than those on the MHC (which seem necessary but not sufficient for the disease to develop), who are we picking up by screening with, for example, ICA? To our surprise [16], but now confirmed in other studies, [17-19] the frequency of ICA among healthy children exceeds the prevalence of the disease by a factor of at least 20 . The figure for Sweden was $3 \%$ ICA-positive subjects compared with a prevalence rate of $0.15 \%$. Therefore, if we were to use ICA to screen in order to treat marker-positive children, we would over-treat, as pointed out by Dahlquist [20], a sizable number of children who would not develop Type 1 diabetes despite the presence of this marker.

It is clear that a rigorous understanding of immune markers is necessary before children can be exposed to reagents developed to interfere with their immune system. Whether antibody markers (ICA, insulin autoantibodies(IAA) and GAD654-Ab) alone or in combination with HLA will generate acceptable sensitivity, specificity, and predictive values remains to be determined. Remember that: (1) neither ICA, IAA nor a combination of the two have a $100 \%$ sensitivity, (2) the frequency of these markers in the background population is high compared with the prevalence rate, and (3) the prevalence rate of the disease is too low for these markers to yield a high positive predictive value. It is therefore important that the validity of Type 1 diabetes immune markers, as well as Beta-cell function tests are rigorously determined, and international standardization is a powerful scientific tool with which to achive this. Nonetheless, diabetes immune intervention has already had a number of failures and the question is how many of these expensive trials are we willing to pay for, and at what risk to the patients [21]? The lesson to be learned from the well-thought out, randomized, controlled clinical trials with cyclosporin $[22,23]$ was that even this powerful immunosuppressive agent could not maintain insulin independence.

\section{How to treat}

The formation of an immune response to an antigen is a smorgasbord of molecular reactions, many yet to be uncovered. Most of these reactions are potential targets for therapy although some are more attractive than others as already indicated by Pozzilli and colleagues. It would be useful to stage the prodrome of Type 1 diabetes although we need to understand what is being staged: reactions which are related to the disease itself (primary) or to its consequences (secondary reactions). This debate has currently hit hard in the field of AIDS research since it is now questioned whether it is the virus (primary) or the immune reaction to the virus (secondary) which kills the $T$ lymphocyte. Similar reactions are also clearly implicated in human viral hepatitis. Since our knowledge of the aetiology of Type 1 diabetes is nearly nonexistent, clinical trials in individuals whom we call pre-diabetic subjects or in newly-diagnosed patients need to follow rigorous protocols such as those used in the cyclosporin trials [22, 23]. Current activities by the Islet Cell Antibody Register of Users Study (ICARUS) group to establish protocols, for example, to be used in the trial with nicotinamide and the activity by the International Diabetes Immunotherapy Group (IDIG) to co-ordinate these trials are to be commended. Continued discussions and exercises in the design of such protocols should be encouraged. This also includes exercises in insulin therapy to precede the onset of hyperglycaemia in marker-positive individuals with a documented decrease in Beta-cell function. Controlled clinical trials should indeed be mandatory. In the past 15 years since Ludvigsson et al. [24] treated ten recentonset diabetic children with plasmapheresis in 1978 we have witnessed a flurry of "quick fixes." Type 1 diabetes is too formidable an opponent for these.

\section{References}

1. Lernmark $\AA$, Molenaar JL, van Beers WAM et al. (1991) The fourth international serum exchange workshop to standardize cytoplasmic islet cell antibodies. Diabetologia 34: 534-535

2. Kuglin B, Kolb H, Greenbaum C, Maclaren NK, Lernmark A, Palmer JP (1990) The fourth international workshop on the standardisation of insulin autoantibody measurement. Diabetologia 33: 638-639 
3. Palmer JP, Asplin CM, Clemons P et al. (1983) Insulin antibodies in insulin-dependent diabetics before insulin treatment. Science 222: $1337-1339$

4. Karlsen AE, Hagopian WA, Grubin CE et al. (1991) Cloning and primary structure of a human islet isoform of glutamic acid decarboxylase from chromosome 10. Proc Natl Acad Sci US 88 : $8337-8341$

5. Karlsen AE, Hagopian WA, Petersen JS et al. (1992) Recombinant glutamic acid decarboxylase representing a single isoform expressed in human islets detects IDDM associated $64 \mathrm{~K}$ autoantibodies. Diabetes (in press)

6. Hagopian WA, Dube S, Karlsen AE, Grubin C, Lernmark $\AA$ (1991) Analysis of glutamic acid decarboxylase shows autoantigen heterogeneity in dog an human islets. Diabetologia 34: 97A [Abstract at the Dublin EASD meeting]

7. Grubin C, Daniels T, Karlsen AE, Boel E, Hagopian WA, Lernmark $\AA$ (1992) The cDNA-directed, in vitro-synthesized nascent peptide of glutamic acid decarboxylase (GAD2) is the autoantigen in insulin-dependent diabetes. Clin Res 40: 299A (Abstract)

8. Kaufman DJ, Erlander MG, Clare-Salzer M, Atkinson MA, Maclaren NK, Tobin AJ (1992) Autoimmunity to two forms of glutamate decarboxylase in insulin-dependent diabetes mellitus. J Clin Invest 89: 283-292

9. Lee KU, Kim MK, Amano K et al. (1988) Preferential infiltration of macrophages during early stages of insulitis in diabetesprone $\mathrm{BB}$ rats. Diabetes 37: 1053-1058

10. Lee KU, Amano K, Yoon JW (1988) Evidence for initial involvement of macrophage in development of insulitis in NOD mice. Diabetes 37:989-991

11. Lo D, Burkly LC, Widera $G$ et al. (1988) Diabetes and tolerance in transgenic mice expressing class II MHC molecules in pancreatic beta cells. Cell 53: 159-168

12. Pipeleers DG, In't Veld PA, Pipeleers-Marichal MA, Gepts W, van de Winkel M (1987) Presence of pancreatic hormones in islet cells with MHC-class II antigen expression. Diabetes 36: 872876

13. In't Veld PA, Pipeleers DG (1988) In situ analysis of pancreatic islets in rats developing diabetes: appearance of nonendorcrine cells with surface MHC class II antigens and cytoplasmic insulin immunoreactivity. J Clin Invest 82: 1123-1128

14. Sutherland DER, Goetz FC, Sibley RK (1989) Recurrence of disease in pancreas transplants. Diabetes 38:85-87

15. Dahlquist $G$, Blom L, Tuvemo T, Nyström L, Sandström A, Wall S (1989) The Swedish childhood diabetes study - re- sults from a nine year case register and one year case-referent study indicating that Type 1 (insulin-dependent) diabetes mellitus is associated with both Type 2 (non-insulin-dependent) diabetes mellitus and autoimmune disorders. Diabetologia 32: $2-6$

16. Landin-Olsson M, Karlsson A, Dahlquist G, Blom L, Lernmark A, Sundkvist G (1989) Islet cell and other organ-specific autoantibodies in all children developing Type 1 (insulinindependent) diabetes mellitus in Sweden during one year and in matched control children. Diabetologia 32: 387-395

17. Karjalainen J (1990) Islet cell antibodies as predictive markers for IDDM in children with high background incidence of disease. Diabetes 39: 1144-1150

18. Bonifacio E, Bingley PJ, Shattock M et al. (1990) Quantification of islet cell antibodies and prediction of insulin dependent diabetes. Lancet 335: 147-149

19. Levy-Marshal C, Tichet J, Fajardy I, Gu XF, Dubois F, Czernichow P (1992) Islet cell antibodies in normal French school children. Diabetologia 35: 577-582

20. Dahlquist $G$ (1991) Epidemiological and ethical consideration in trials with immunotherapy in pre-Type 1 (insulin-dependent) diabetes mellitus. Diabetologia 34:536 (Letter)

21. Feutren G, Mihatsch MJ (1992) Risk factors for cyclosporine-induced nephropathy in patients with autoimmune diseases. $\mathrm{N}$ Engl J Med 326: 1654-1660

22. The canadian-european randomized control trial group (1988) Cyclosporin-induced remission of IDDM after early intervention: association of $1 \mathrm{yr}$ of cyclosporin treatment with enhanced insulin secretion. Diabetes 37: 1574-1582

23. Assan R, Feutren G, Sirmaí J et al. (1990) Plasma C-peptide levels and clinical remissions in recent-onset type 1 diabetic patients treated with cyclosporin $\mathrm{A}$ and insulin. Diabetes 39: $768-774$

24. Ludvigsson J, Heding L, Liedén G, Marner B, Lernmark A (1983) Plasmapheresis in the initial treatment of insulin-dependent diabetes mellitus in children. Br Med J 286: 176-178

Prof. A. Lernmark

Department of Medicine RG-20

University of Washington

Seattle, WA 98195

USA 